\title{
Health and physiological quality of corn seeds treated with fungicides and assessed during storage ${ }^{1}$
}

\author{
Christiano de Sousa Machado de Matos², Ellen Noly Barrocas²*, \\ José da Cruz Machado², Francisco Cardoso Alves ${ }^{3}$
}

\begin{abstract}
At post-harvest period, quality of corn seeds may be influenced by several important factors such as: presence of harmful microorganisms, chemical treatments, host species genotype and storage conditions. The objective of this study was to evaluate the performance of corn seeds, hybrids 2B 688 and 2B 710, with high incidence of fungus Fusarium verticillioides

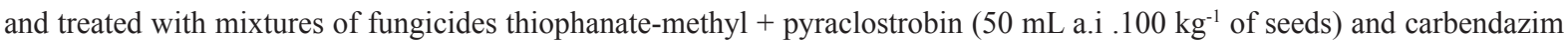
+ thiram + micronutrients $\left(100 \mathrm{~mL}\right.$ a.i $.100 \mathrm{~kg}^{-1}$ of seeds) during six months storage. Performance assessments of seeds were carried out at $0,30,60,90,120$, and 180 days storage. The incidence of $F$. verticillioides, as well as physiological quality, germination, vigor, stand of plants, emergence speed index, and dry matter weight were assessed. It has been verified that seed treatment with fungicide mixtures was efficient for ensuring seed physiological quality of both genotypes and to reduce incidence of $F$. verticillioides on treated seeds. By contrast, analysis between treatments with fungicides, within each period assessed and each treatment as compared to control along storage period was verified clear benefits on emergence of seeds after treatment with fungicides.
\end{abstract}

Index terms: Fusarium verticillioides, seed treatment, fungicide.

\section{Qualidade fisiológica e sanitária de sementes de milho tratadas com fungicidas e avaliadas durante o armazenamento}

\begin{abstract}
RESUMO - No período pós-colheita, a qualidade das sementes de milho é influenciada por diversos fatores importantes, entre os quais: presença de microrganismos nocivos, tratamento químico, genótipo da espécie hospedeira e condições de armazenamento. O objetivo deste trabalho foi avaliar o desempenho das sementes dos híbridos de milho 2B 688 e 2B 710, com alta incidência de Fusarium verticillioides, mediante tratamento das sementes com misturas dos fungicidas pyraclostrobin+tiofanato metílico (50 mL i.a. $100 \mathrm{Kg}^{-1}$ de sementes) e carbendazim+thiram+ micronutrientes (100 mL i.a. $100 \mathrm{Kg}^{-1}$ de sementes), durante seis meses de armazenamento. As avaliações de desempenho das sementes foram realizadas aos 0, 30, 60, 90, 120 e 180 dias após o início do ensaio. Foram avaliados: incidência de F. verticilliodes; qualidade fisiológica; germinação; vigor; estande; índice de velocidade de emergência; e peso de matéria seca. Verificou-se que o tratamento das sementes, com ambas as misturas, foi eficiente em assegurar a qualidade fisiológica das sementes, de ambos os genótipos e reduzir a incidência de $F$. verticillioides nas sementes tratadas. Pelas análises de contrastes entre os tratamentos fungicidas, dentro de cada época avaliada e de cada tratamento, em comparação à testemunha, ao longo do período de armazenamento, foram verificados evidentes benefícios às sementes, após o tratamento fungicida.
\end{abstract}

Termos para indexação: Fusarium verticillioides, tratamento de sementes, fungicida.

\section{Introduction}

The treatment of corn seeds is a practice that is becoming more important and common among agricultural producers, by the direct reflexes on health and physiological quality of seeds that are intended to the sowing (Machado et al., 2006; Machado, 2000). However, the most adequate moment to

${ }^{1}$ Submitted on $06 / 28 / 2011$. Accepted for publication on $05 / 18 / 2012$. ${ }^{2}$ Departamento de Fitopatologia, Universidade Federal de Lavras, 37200-000Lavras, MG, Brasil. perform the treatment of seeds still causes uncertainties among producers. Before storage, the seed treatment may be performed jointly with processing, lowering operational costs; besides avoiding possible damages caused by microorganisms during that period. However, the amount of treated seeds may be beyond the need for the next sowing and in this case the fate of remaining seeds from the treated seed lots may

${ }^{3}$ EMATER, Universidade Federal de Lavras, 37200-000 - Lavras, MG, Brasil. *Corresponding author <ellennoly@gmail.com> 
represent a high monetary burden to producer.

One of the main reasons for seed treatment with fungicides is the control of microorganisms, which are associated to them, and whose action has been cause of unacceptable losses. Among the fungi considered harmful to corn crop, the fungus Fusarium verticillioides (Sacc.) Nirenberg (syn. F. moniliforme J. Sheld.) should be a problem in the maize culture, once it is one of the fungi found with the highest level of incidence on seeds and grains (Goulart, 1998; Mazzani et al., 2001; Valenciano et al., 2004). However, the correlation between presence of this fungus and reduction on seed vigor is still controversial. $F$. verticillioides is an important fungus within the complex of microorganisms by causing mold-damage and production of mycotoxins, which are responsible by severe diseases on animals and humans, as well as rotting of seeds, roots, base of stem and death of seedling; mainly when the sowing is performed under conditions of high moisture and low temperatures (Reis and Casa, 1996; Fernandes and Oliveira, 2000; Sartori et al., 2004; Casa et al., 1995).

Another important aspect related to fungus $F$. verticillioides is its high survival capacity in locations in which it was introduced. Such capacity has been assessed by several researchers on crop debris in the field (Cotten and Munkvold, 1998; Nyvall and Kommedahl, 1970). However, during storage, this characteristic is questionable and seems to be directly linked to environmental conditions and storage time to what these seeds have been subjected.

The corn seed treatment has traditionally been accomplished with some fungicides, being captan and thiabendazole the most used products. Recently other products have been commercialized, such as fludioxonil, metalaxyl and tolylfluanid, with a wider spectrum of active ingredients. The use of mixtures of products with complementary mode of action for treating seeds has been a strategy, which in addition to expanding range of pathogens to be controlled prevents development of resistance by population of target-microorganisms of these products (Machado, 2000; Maude, 1996).

Thus, the proposal in this study was to assess interaction of chemical treatment with the corn seed performance, considering presence of fungus Fusarium verticillioides and storage periods of these seeds, under natural environmental conditions.

\section{Material and Methods}

The study was conducted at Department of Plant Pathology, Federal University of Lavras, State of Minas Gerais, Brazil. Seeds of two corn hybrids, 2B 688 (Hybrid 1) and 2B 710 (Hybrid 2), from Dow AgroSciences ${ }^{\circledR}$, with germination of $95 \%$ e $100 \%$, respectively, both with $100 \%$ incidence of fungus
Fusarium verticillioides were used and assessed according to Brazilian Seed Testing Rules (Brasil, 2009a) and Brazilian Seed Healthy Rules (Brasil, 2009b). The seed treatment with fungicides was performed with mixtures of the following active ingredients: pyraclostrobin + thiophanate-methyl, in dosage of $50 \mathrm{~mL}$ a.i. $100 \mathrm{~kg}^{-1}$ of seeds; and carbendazim + thiram + micronutrients, in dosage of $100 \mathrm{~mL}$ a.i. $100 \mathrm{~kg}^{-1}$ of seeds, both already formulated by manufacturer. For each seed treatment $0,5 \mathrm{Kg}$ of seeds were used. The chemical products were directly applied to seed samples, previously moistened with water in the ratio of $1 \mathrm{~L} .100 \mathrm{~kg}^{-1}$ of seeds into $10 \mathrm{~kg}$ capacity plastic bags, and the mixture homogenization was then performed by manual shaking; and after $2 \mathrm{~min}$. of agitation, seeds were dried in the shade. After each treatment, seeds were packaged into multi-walled paper bags and stored under natural environmental conditions. The relative humidity was monitored during all experiment.

A completely randomized experimental design was used, with treatments arranged into a factorial scheme $6 \times 2$ [6 storage periods $(0=$ control, and $30,60,90,120,180$ days after seed treatment)] x [2 fungicide mixtures (pyraclostrobin + thiophanatemethyl and carbendazim + thiram + micronutrients)], with four replications for each treatment.

At each predefined period, assessments were performed by the following tests:

Health test: was conducted with four replications of 50 seeds each, for each seed sample by the blotter test method, according to recommendations of Brasil (2009b).

Germination test: was carried out with four replications of 50 each, for each seed sample, which were evenly distributed on two sheets of Germitest ${ }^{\circledR}$ type paper, previously moistened with water, in the ratio of 2.5 times the mass of dry substrate and kept at $25^{\circ} \mathrm{C}$; assessments followed recommendations of Brasil (2009a).

Emergence speed index (ESI): for this test, the sowing was performed in seed-beds containing a mixture of sand: soil (2:1 ratio), with four replications of 50 seeds each, for each seed sample. Seedlings were daily assessed after first emergence day, by computing the number of emerged seedlings until stand stabilization, which occurred at the $23^{\text {rd }}$ day; the ESI was determined according to equation of Maguire (1962).

Weight of dry mass: for this evaluation, 30 days after seedling emergence within plastic trays in each replication, emerged plants were cut at soil level and placed into air circulation stove, at the temperature of $70{ }^{\circ} \mathrm{C}$, where they remained until constant weight. Subsequently, dry weight was determined.

Cold test: conducted with four replications of 50 seeds each, for each treatment, into plastic germination boxes 
(dimensions - $11 \mathrm{~cm}$ x $11 \mathrm{~cm}$ x $3.5 \mathrm{~cm}$ - gerbox) containing a mixture of sand: soil (2:1 ratio), moistened until $60 \%$ of the retention capacity. After the sowing, gerboxes were kept covered into a cold chamber $\left(10^{\circ} \mathrm{C}\right)$, during seven days. After such period, gerboxes were uncovered and maintained into a growth chamber, previously adjusted to a temperature range of $25^{\circ} \mathrm{C}$ to $30^{\circ} \mathrm{C}$, during seven days. Subsequently, the number of normal seedling was computed and results of the final counting were expressed in percentages.

The statistical analyses of data were performed using the statistical program SISVAR (Ferreira, 2011). For comparison of means the Tukey test, at $5 \%$ probability was used; and according to nature of data, the regression analysis was used.

\section{Results and Discussion}

During assessment period variations of relative humidity were recorded between $40 \%$ and $98 \%$; with means ranging between $55 \%$ and $78.5 \%$.

According to the results of the health test (Figures 1A and 1B), it was observed that seed treatment with the fungicides has reduced the incidence of fungus Fusarium verticillioides for both corn genotypes. Such reduction, which occurred at the first assessment time, was kept along all assessment period; which has not occurred with non-treated seeds. The incidence of fungus has been maintained along storage, demonstrating survival capacity of this microorganism under normal storage conditions.
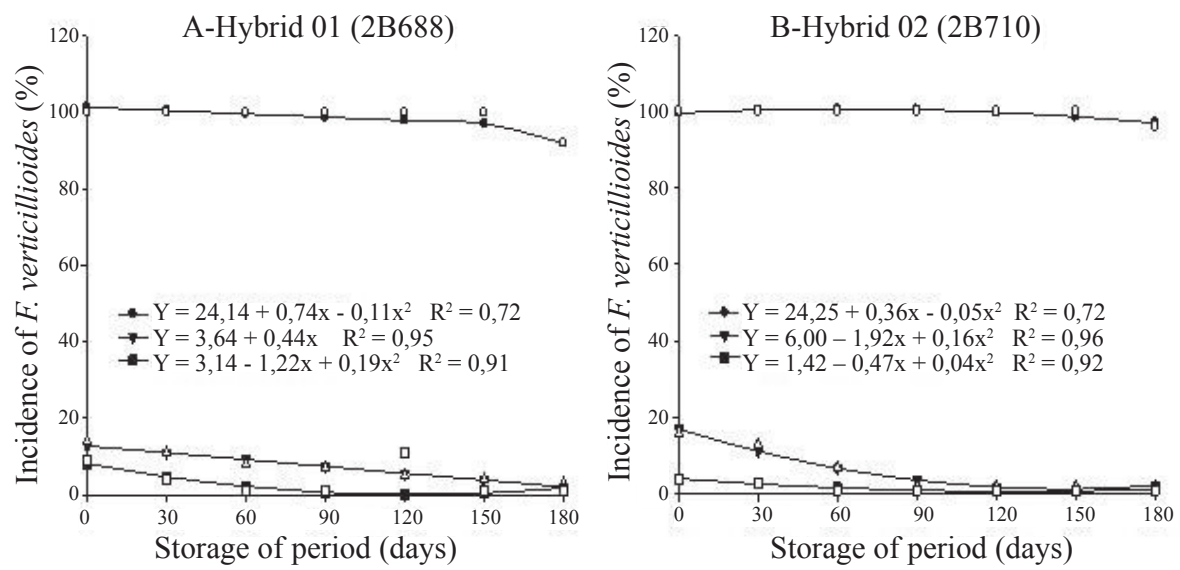

Figure 1. Incidence of fungus Fusarium verticillioides on seeds of the corn hybrids 2B 688 and 2B 710 (A and B). ( - ) = without treatment (control); and $(*)=$ treated with the mixtures of the fungicides pyraclostrobin + methyl-thiophanate and $(*)=$ carbendazim + thiram + micronutrients, in relation to storage period.

As it can be observed, although none of the mixtures of fungicide products have eradicated the pathogen totally from the lots assessed, it should be considered that the reduction in incidence, above $80 \%$ for both seed lots, can be considered of great importance from epidemiological view point. This may signify that reduction on the fungal load on the seeds, after treatment, may not be sufficient to cause damages to the establishment of the crop in the field.

There are reports in the literature, in which it is assumed that some species of Fusarium, when associated to seeds, show a decline on its percentage of occurrence along the storage period; independent of storage conditions, once such conditions are not favorable for development of this microorganism group (Kabeere et al., 1997; Neto et al., 2007). Other species, however, may behave differently under the same conditions, i.e., varying according to host, environmental conditions, and length of period in which seeds are stored.

Tanaka (2001) verified that survival of $F$. verticillioides on corn seeds was favored when the seeds were stored into cold and dry chamber; and disfavored when the storage occurred under natural environmental conditions. The same author reports that a period of 12 months storage was not sufficient to eradicate the pathogen from seeds, and that pathogen viability was maintained under different storage conditions. In another study performed by Neto et al. (2007) it was observed that corn seeds with $29.8 \%$ and $100 \%$ of Fusarium graminearum incidence were free of the fungus at the end of 12 months storage. Vilela et al. (2010) have reported that under natural and cold and dry environmental conditions it has not observed significant decrease on incidence of Fusarium oxysporum f.sp. phaseoli on infected seeds stored during 10 months.

In relation to seed germination (Figures 2A and 2B) there has been increment on percentage of germinated seeds for both seed lots treated in all periods assessed, as compared to control. The seeds of both genotypes assessed, treated with mixtures of fungicides, which were used in this study, could 
be commercialized until end of storage period, still within certification standards.

By the results of the vigor test, all variables: plant stand and dry mass weight for both genotypes assessed for the fungicides seed treatments have kept mean values above values of the control treatment, along six months storage time.
From the evaluation of ESI (Figures 3A and 3B) it was observed that values were linear and sloped-down for seed stored during six months. Despite this decrease, it was clear that the values representing vigor indexes of both fungicide treatments were higher than the control, untreated seeds, with more accentuated values for seeds of hybrid 1 than for hybrid 2 .
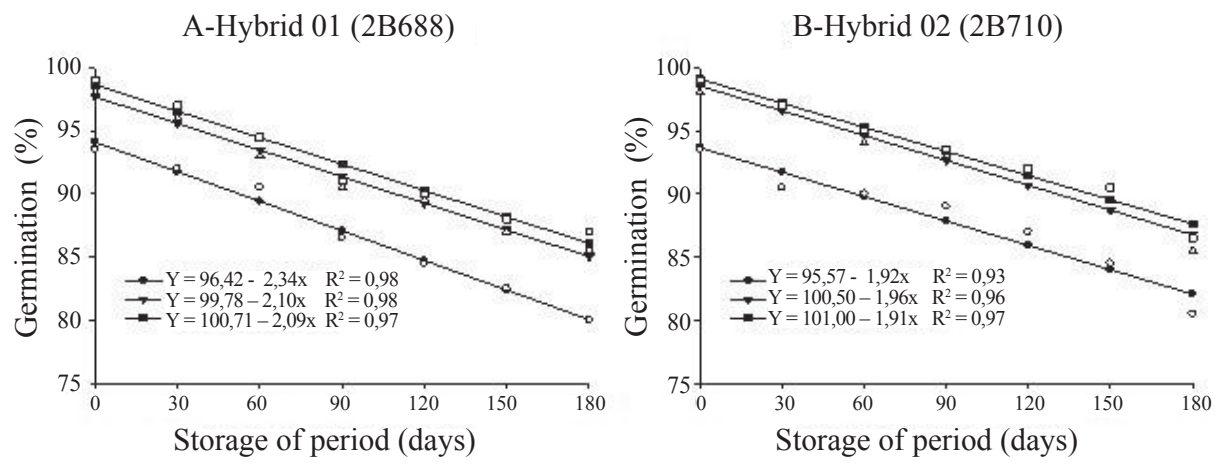

Figure 2. Percentage of germination of the seeds of the corn hybrids 2B 688 and 2B 710 (A and B) obtained from seeds: $(--)=$ without treatment (control); and $(-)=$ treated with the mixtures of the fungicides pyraclostrobin + methyl-thiophanate and $(*)=$ carbendazim + thiram + micronutrients, in relation to storage period.
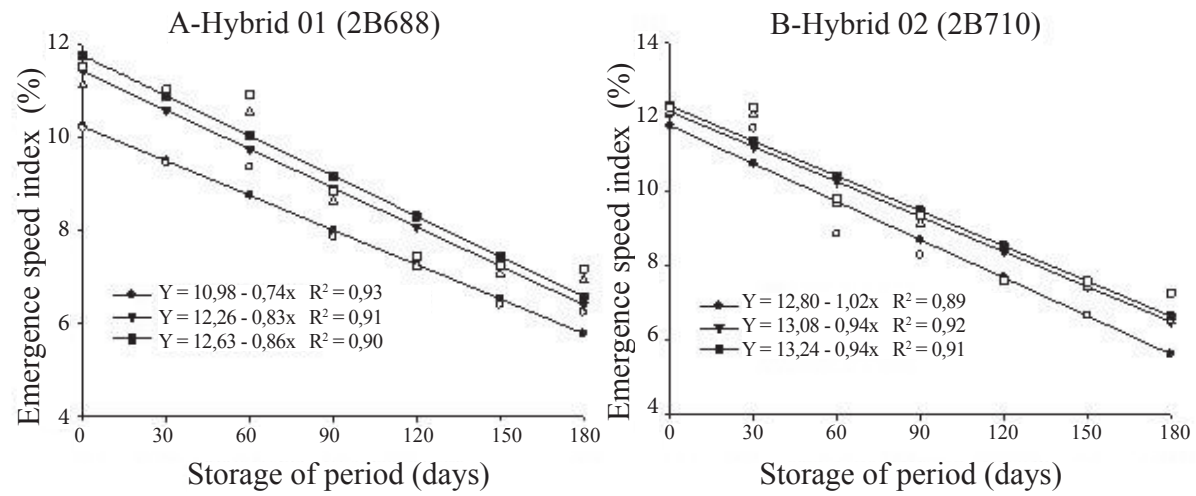

Figure 3. Emergence speed index of the seedlings of the corn hybrids 2B 688 and 2B 710 (A and B) obtained from seeds: $(--)=$ without treatment (control); and $(-)=$ treated with the mixtures of the fungicides pyraclostrobin + methyl-thiophanate and $(*)=$ carbendazim + thiram + micronutrients, in relation to storage period.

Emergence speed index is an important component in assessing seed quality, being correlated to fast establishment of plants in the field. Plants with higher ESI present higher capacity to resist to some types of stresses, besides escaping with higher frequency from infection of some pathogens present in soil. Despite the natural vigor decrease of stored seeds, mainly under natural environment, it was also observed that vigor values were higher than values achieved for control, when the two fungicide mixtures were assessed.

Similarly, for the variables already cited, the seeds treated with the fungicide mixtures kept the values of final stand along the storage period assessed (Figures 4A and 4B) and they were higher than the control. In addition, there has been no statistically significant difference between the two fungicide mixtures assessed.

The results of the cold test (Figures 5A and 5B) followed reasonably the same trend presented by seeds in the germination test, as well as in relation to values attained on the assessment performed for emergence and dry matter weight of plants. It is timely to remind that the germination test provides indicative data of the highest germination percentages of the seed lot whereas the cold test provides information about the capacity of the seeds to overcome stress conditions in the field. (Vieira and Carvalho, 1994). 

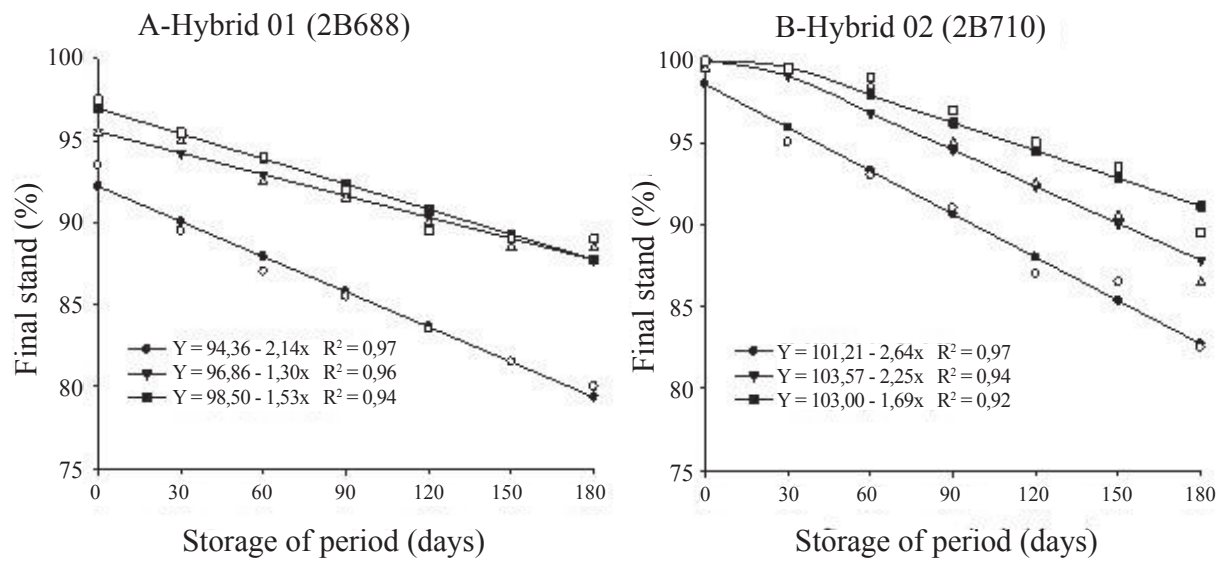

Figure 4. Final stand of seedlings of the corn hybrids 2B 688 and 2B 710 (A and B) obtained from seeds: $(-)=$ without treatment (control); and $(-)=$ treated with the mixtures of the fungicides pyraclostrobin + methyl-thiophanate and $(-)=$ carbendazim + thiram + micronutrients, in relation to storage period.
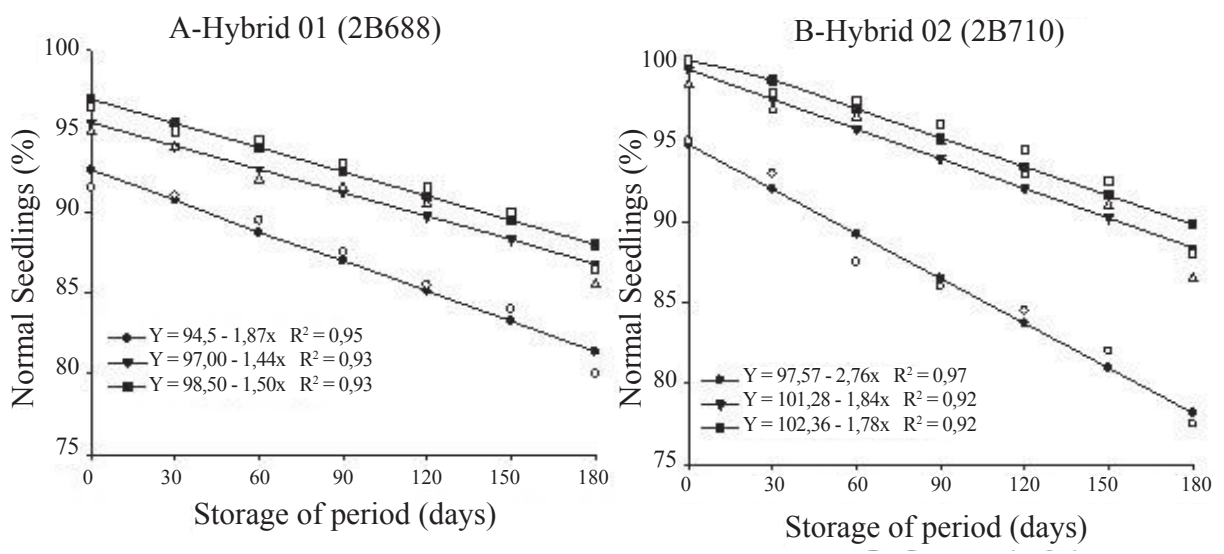

Figure 5. Percentage of normal seedlings assessed by the cold test obtained from seeds of the corn hybrids 2B 688 and 2B 710 (A and B). $(-)=$ without treatment (control); and $(-)=$ treated with the mixtures of the fungicides pyraclostrobin + methyl-thiophanate and $(-)=$ carbendazim + thiram + micronutrients, in relation to storage period.

Dry matter, despite the increment of values indicative of seed vigor, induced by treatment with the mixtures of the products assessed, the weight of dry matter of seedling of any of the two genotypes was translated in statistically significant increase for this variable (Figures 6A and 6B). Mainly in relation to periods 0 (control) and 30 days assessed for hybrid 2, when both presented small differences in the following periods. Despite the small increase on dry matter, the vigor values, higher than for values of control period may be a good indicative of increase on final yield.

In this study, the increment in mean values of all variables indicating the physiological quality of seeds for both fungicide mixture treatments can be the result of the decrease in F. verticillioides incidences associated to seeds promoted by those chemicals.

In face of the results of the seed health, it is worth emphasizing the equivalence of both fungicide mixtures in controlling F. verticillioides on corn seeds; which supports the strategy of integrating active ingredients of products with different properties. The formulation of systemic products such as carbendazim and thiophanate - methyl, both belonging to benzimidazole group, in association with products like thiram and pyraclostrobin, is a way to control not only Fusarium species, but also other species of fungi that normally are associated to corn seeds (Casa et al., 1995; Goulart and Fialho, 1994, 1999).

Despite conflicting information in literature on influence of F. verticillioides in relation to germination and emergence of corn seeds (Von Pinho et al., 1995; Pinto, 2000; Moraes et al. 2003), in this study it was evident that the indexes of vigor assessed reflect the influence of this fungus on germination, emergence speed index, and vigor of seeds. The increase on these values at the initial period of assessment reflects the action of the fungus on the seed performance. 

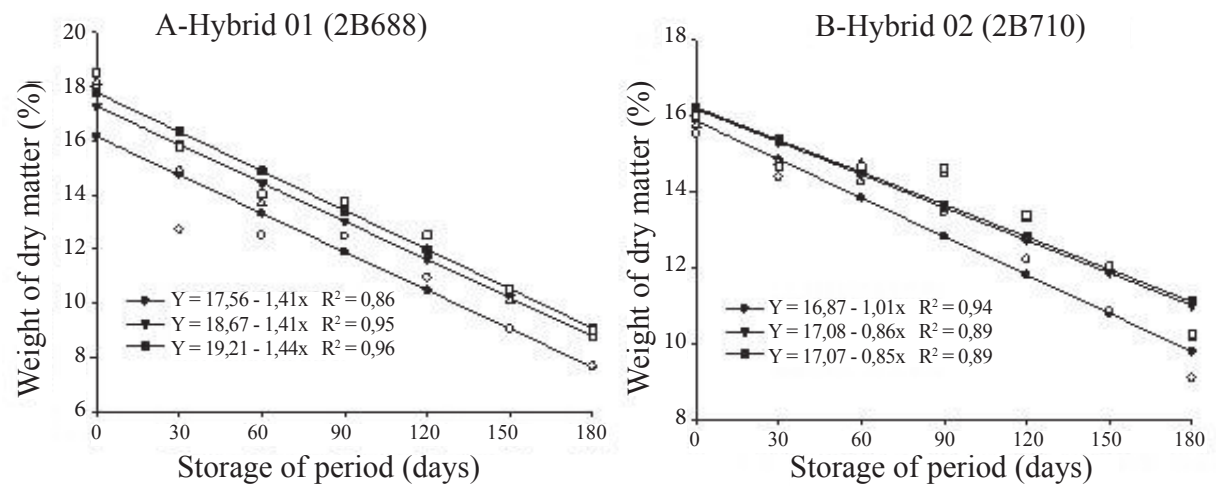

Figure 6. Percentage of weight of dry matter of seedlings of the corn hybrids 2B 688 and 2B 710 (A and B) obtained from seeds: $(-)=$ without treatment (control); and $(-)=$ treated with the mixtures of the fungicides pyraclostrobin + methylthiophanate and $(*)=$ carbendazim + thiram + micronutrients, in relation to storage period.

To control Fusarium verticillioides in association with corn seeds some fungicides formulated single or in mixture, such as: captan, thiram, carbendazim + thiram, tolylfluanid, fludioxonil, fludioxonil + metalaxyl-M, carboxin + thiram; have been registered for use in Brazil (Brasil, 2011). In literature reports on corn seed treatment reveal the efficacy of several fungicides in the control of Fusarium verticillioides and other pathogenic fungi which are associated to seeds in that crop (Oliveira et al.,1999; Von Pinho et al., 1995; Goulart e Fialho, 1999) emphasized that the products tolylfluanid, tolylfluanid + methyl-thiophanate and captan are the most efficient in controlling $F$. verticillioides as well as in guaranteeing the vigor of treated seed lot. Reported good indexes of control of that same fungus with the mixture (metalaxyl + thiabendazole) also observed satisfactory results in controlling the referred to fungus with the mixtures: thiabendazole + captan, thiabendazole + thiram, tolylfluanid + carbendazim, and tolylfluanid + methyl-thiophanate.

The health seed treatment with fungicides of strobilurin group represented an advance, not only in the control of pathogenic microorganisms but also on providing conditions for seeds to express their physiological potentiality as it has been pointed by some researchers in that field. According to Venancio et al. (2003), these fungicides promotes improvement on absorption of nitrogen and carbon by the plant, delay on senescence, and lengthening of photosynthetic activity, keeping the plant green for a longer time.

\section{Conclusions}

The treatment of seeds of corn hybrids 2B 688 and $2 \mathrm{~B}$ 710 with mixtures of the fungicides pyraclostrobin + methylthiophanate and carbendazim + thiram + micronutrients reduces incidence of fungus Fusarium verticillioides, with significant increase on germination as well as on vigor of seeds, after six months of storage under natural environmental conditions.

The fungicide treatment of corn seeds with mixtures of active ingredients is also beneficial when performed before storage.

\section{Acknowledgements}

The authors would like to thank: Mr. Sérgio Korello (BASF Crop Protection), FAPEMIG, CAPES, and CNPq by their support in the development of this study.

\section{References}

BRASIL. Manual de Análise Sanitária de Sementes. Ministério da Agricultura, Pecuária e Abastecimento, Brasília: MAPA/ACS, 2009a, 200p. http://www.agricultura.gov.br/arq_editor/file/3376_manual_de_analise_ sanitaria_de_sementes.pdf

BRASIL. Ministério da Agricultura, Pecuária e Abastecimento. Regras para análise de sementes. Secretaria de Defesa Agropecuária Brasília: MAPA/ ACS, 2009b. 395p. http://www.agricultura.gov.br/arq_editor/file/2946_regras_ analise_sementes.pdf

BRASIL. Ministério da Agricultura, Pecuária e Abastecimento. Coordenação Geral de Agrotóxicos e Afins/DFIA/SDA AGROFIT. Sistemas de Agrotóxicos Fitossanitários. http://agrofit.agricultura.gov.br/agrofit_cons/principal_agrofit_ cons. Acesso em: 13 jun. 2011.

CASA, R.T.; REIS, E.M.; MEDEIROS, C.A.; MOURA, F.B. Efeito do tratamento de sementes de milho com fungicidas, na proteção de fungos do solo, no Rio Grande do Sul. Fitopatologia Brasileira, v.20, p. 633-637, 1995.

COTTEN T, K.; MUNKVOLD, G.P. Survival of Fusarium moniliforme, F. proliferatum, and F. subglutinans in maize stalk residue, Phytopathology, v.88, n.6, p.550-555, 1998. http://apsjournals.apsnet.org/doi/pdfplus/10.1094/ phyto.1998.88.6.550 
FERNANDES, F.T.; OLIVEIRA, E. Principais doenças na cultura do milho. Sete Lagoas: EMBRAPA - CNPMS, 2000 (Circular técnica, 26).

FERREIRA, D.F. SISVAR: A computer statistical analysis system. Ciência e Agrotecnologia, v.35, n.6, 1039-1042, 2011. http://www.scielo.br/pdf/cagro/ v35n6/a01v35n6.pdf

GOULART, A.C.P.; FIALHO, W.F.B. Incidência e controle de Fusarium moniliforme Sheldon em sementes de milho. Revista Brasileira de Sementes, v.21, n.1, p.216-221, 1999. http://www.abrates.org.br/revista/artigos/1999/ v21n1/artigo32.pdf

GOULART, A.C.P.; FIALHO, W.F.B. Eficiência de fungicidas no controle de patógenos em sementes de milho (Zea mays L.). Informativo Abrates, v.4, n.3, p.55-59, 1994.

GOULART, A.C.P. Tratamento de sementes de soja com fungicidas para o controle de patógenos. Fitopatologia Brasileira, v.23, n.2, p.127-131, 1998.

KABEERE, F.; HILL, M.J.; HAMPTON, J.G. Effect of mayze seed storage conditions on the survival of Fusarium spp. Seed Science Technology, v.25, n.2, p.329-332, 1997.

MACHADO, J.C.; WALQUI, J.M.; SANTOS, J.P.; REICHENBACH, J.W. Tratamento de sementes no controle de fitopatógenos e pragas. Informe Agropecuário, v.27, n.232, p.76-87, 2006.

MACHADO, J.C. Tratamento de sementes no controle de doenças. Lavras: UFLA/FAEPE, 2000.138p.

MAGUIRE, J.D. Speed of germination-aid in selection and evaluation for seedling emergence and vigor. Crop Science, v.2, n.1, p.176-177, 1962.

MAUDE, R.B. Seedborne disease and their control: principles and practice. Wallingford: CAB International, 1996, 280p.

MAZZANI, C.; BORGES, O.; LUZÓN, O.; BARRIENTOS, V.; QUIJADA, P. Occurrence of Fusarium moniliforme and fumonisins in kernels of maize hybrids in Venezuela. Brazilian Journal of Microbiology, v.32, p.345-349, 2001. http://www.scielo.br/pdf/bjm/v32n4/11117.pdf

MORAES, M.H.D.; MENTEN, J.O.M.; GRAVENA, J.C.; ALVES, C.A. Controle químico de Fusarium moniliforme em sementes de milho: metodologia de avaliação e efeitos sobre a qualidade fisiológica. Fitopatologia Brasileira, v.28, n.6, p.626-632, 2003. http://www.scielo.br/pdf/fb/v28n6/a08v28n6.pdf

NETO, F.X.B.; REIS, E.M.; CASA, R.T. Viabilidade de Fusarium graminearum em sementes de trigo durante o armazenamento. Summa Phytopathologica, v.33, n.4, p.414-415, 2007. http://www.scielo.br/pdf/sp/ v33n4/a17v33n4.pdf
NYVALL, R.F.; KOMMEDAHL, T. Saprophytism and survival of Fusarium moniliforme in corn stalks. Phytopathology, v.60, p.1233-1235, 1970.

OLIVEIRA, W.F.; MIRANDA, B.A.; CAETANO, F.V.; MACHADO, L.A.; RAMALHO, V. Efeito de produtos fitossanitários no tratamento de sementes de milho (Zea mays L.), visando ao controle de Fusarium moniliforme (Sheld). Pesquisa Agropecuária Tropical, v.29, n.1, p.65-69, 1999.

PINTO, N.F.J.A. Tratamento fungicida de sementes de milho contra fungos do solo e o controle de Fusarium associado às sementes. Scientia Agricola, v.57, n.3, p.483-486, 2000.

REIS, E.M.; CASA, R.T. Manual de identificação e controle de doenças de milho. Passo Fundo: Aldeia Norte, 1996. 80p.

SARTORI, A.F.; REIS, E.M.; CASA, R.T. Quantificação da transmissão de Fusarium moniliforme de sementes para plântulas de milho. Fitopatologia Brasileira, v.29, n.4, 2004. http://www.scielo.br/pdf/fb/v29n4/a18v29n4.pdf

TANAKA, M.A.S. Sobrevivência de Fusarium moniliforme em sementes de milho mantidas em duas condições de armazenamento. Fitopatologia Brasileira, v.26, n.1, p.60-64, 2001. http://www.scielo.br/pdf/fb/v26n1/ a10v26n1.pdf

VALENCIANO, J.B.; CASQUERO, P.A.; BOTO, J.A. Influence of sowing techniques and pesticide application on the emergence and the establishment of bean plants (Phaseolus vulgaris L.). Agronomie, v.24, n.2, p.113-118, 2004. http://www.agronomy-journal.org/index.php?option=com_article\&access=sta ndard\&itemid=129\&url=/articles/agro/abs/2004/02/a4207/a4207.html

VENANCIO, W.S.; RODRIGUES, M.A.T.; BEGLIOMINI, E.; SOUZA, N.L. Physiological effects of strobilurin fungicides on plants . Ciência Agrícola Engenharia, v.9, n.3, p.59-68, 2003. http://publicatio.uepg.br/index. php/exatas/article/viewfile/164/38

VIEIRA, R.D.; CARVALHO, N.M. Testes de vigor em sementes. Jaboticabal: FUNEP, 1994.164p.

VILELA, M.; MACHADO, J.C.; BARROCAS, E.N.; ASSIS, A.C.C. Qualidade de sementes de feijoeiro infectadas por Fusarium oxysporum f. sp. phaseoli e viabilidade do fungo durante o armazenamento. Revista Brasileira de Armazenamento, v.35, n.1, p.54-59, 2010.

VON PINHO, E.V.R.; CAVARIANI, C.; ALEXANDRE, A.D.; MENTEN, J.D.M.; MORAES, M.H.D. Efeitos do tratamento fungicida sobre a qualidade sanitária e fisiológica de sementes de milho (Zea mays L.). Revista Brasileira de Sementes, v.17, p.23-28. 1995. http://www.abrates.org.br/ revista/artigos/1995/v17n1/artigo05.pdf 